\title{
Afrix Model: An Approach for Measuring and Managing Reputational Risk for African Banks
}

\author{
Fitzgerald ZINZINDOHOUE \\ Marketing Intelligence Consultant \\ West Africa
}

\begin{abstract}
This research intends to identify corporate reputation drivers and ascertain how African banks brand preference and performance can derived from them using a designed conceptual framework. The methodological approach for the study encompasses a desk research reviewing the existing literature and a qualitative study. The theoretical framework provides a deep understanding of the corporate reputation concept especially dimensions and attributes of existing measurement models. Theories and models are compared. The empirical analysis and discussion of the findings allows the researcher to identify six (06) dimensions and forty (40) attributes relevant to the measurement of corporate reputation in African banks. Reputational risk has been found critical for a bank to be successful and three (03) primary dimensions are of concern: Governance, Relationship with stakeholders and Regulatory compliance. A conceptual model has been proposed to measure and manage efficiently reputational risk.
\end{abstract}

Keywords: Corporate reputation; reputational risk; Competitive advantage; Customers' brand preference; Banks;

\section{Introduction}

Many practitioners and academics have shown interest in defining and measuring corporate reputation during the past decade and this elicited much publications (Feldman, Bahamonde, \&Bellido, 2014; Trotta \& Cavallaro, 2012; Schwaiger, 2004; Babić-Hodovića, Mehića, \&Arslanagić, 2011; Chun, 2005 etc). It seems to be commonly agreed that corporate reputation origins sustainable competitive advantage to organisations that work to manage it efficiently (Walker, 2010; Adeosun \&Ganiyu, 2013; Schwaiger, 2004 etc.). Particularly in the financial industries, with banks "raw material" being depositors' money, reputation may count as a critical factor for a customer while selecting a bank to handle his or her financial transactions (Trotta and Cavallaro, 2012). The banking industry being highly regulated, majors risk to mitigate are defined by the Basel Committee for Banking Supervision (BCBS, 2009) and include: risk of credit, market risk, operational risk and incidentally reputational risk. Yet in Basel II, the majors three risk have a strong and direct weighed effect on capital equity and may purposely limit the bank's level of assets and liabilities. Despite reputational risk seems to not have a significant impact on the bank's assets and liabilities or any regulatory compliance, BCBS (1997:22) claimed that "Reputational risk is particularly damaging for banks since the nature of their business requires maintaining the confidence of depositors, creditors and the general marketplace".

Fortunately, bank leaders recognize the growing role of corporate reputation to achieve business goals and remain competitive (Wang, Yu \& Chiang, 2015). Academics and professionals unanimously agree corporate reputation is predominantly important for banks because of the nature of services they provide, which are not only intangible but are also subject to trust (Trotta \& Cavallaro, 2012). Trust is a base requirement and a direct consequence of the relationship maintained by a bank with its stakeholders, especially its customers (Stansfield, 2006). Banking is a matter of credibility and reputation is of essence. Greenspan (1999) argued that "having a reputation for fair dealing is a profoundly practical virtue" and "Trust is at the root of any economic system based on mutually beneficial exchange". Reputation and trust being its outcome then play a highly critical role in any bank sustainability and profitability. With reputational risk having such importance, it becomes vital to better understand the concept of reputation in the African banking concept, identify the dimensions and attributes relevant for assessing African banks corporate reputation and derive a suitable reputational framework. This paper first examines the definitional landscape, then discusses dimensions and attributes covered by existing 
measurements tools and reputational models. Afterwards, a reputational model named AFRIX (African Financial Institutions Reputation Index) is proposed based on theoretical background and qualitative findings' discussions.

\section{Defining corporate reputation}

Corporate reputation is a wide multidisciplinary and complex concept (Fombrun\& Van Riel, 1997). The 2016's Global RepTrack report highlighted that reputation is "an emotional bond that ensures: customers buy your products, the general public recommend your company, policy makers and regulators give you a license to operate, the financial community invest in you, the media report favourably on your point of view, employees deliver on your strategy..." (Reputation Institute, 2016:5). To allow appropriateness in defining corporate reputation, it appears vitally important to clarify certain terms that seem to have the same meaning, as Barnett, Jermier \& Lafferty (2006:28) pinpointed that Identity, Image and Reputation are still used interchangeably.

\subsection{Image, Identity and Reputation}

According to Gray \& Balmer (1998:696), corporate identity through corporate communication creates corporate image and corporate reputation which can lead to competitive advantage. This is illustrated in Figure 1 below:

\section{Figure 1: Operational model for managing corporate reputation and image}

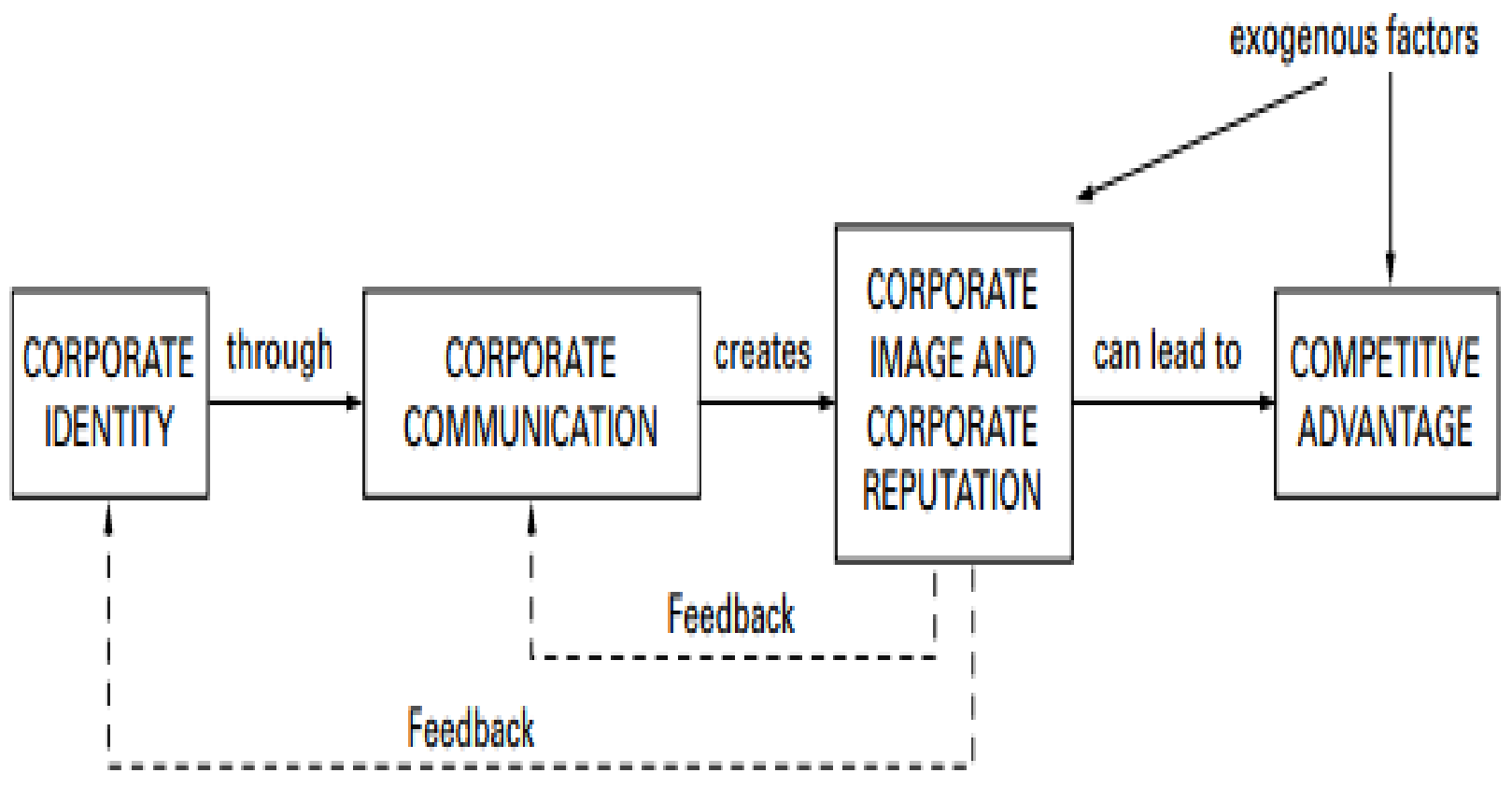

Source: Gray\& Balmer (1998).

Figure 1 shows relation between identity, image and reputation but is not clear about how much image and reputation are different. Bringing this to light, the authors mentioned "corporate image is the immediate mental picture that audiences have of an organization. Corporate reputation, on the other hand, indicates a value judgement about the company's attributes" (Gray\& Balmer, 1998:697).

Corporate reputation has been defined by other scholars as one dimension of corporate image and seen as synonymous with image, corresponding to the overall perception of an organisation (Baybars-Hawks \&Samast, 2013). But, following Dozier's (1993) approach, "reputation may be based on direct experiences as well as on processed communication message". This seems to make a difference between corporate reputation and corporate image as "image" does not require experience, but more rely on processed communication message. What about corporate identity? Though Fombrun and Van Riel (1997) include image and identity in reputation as basic components, Barnett et al. (2006) argued that while image reflect the external perception of the organisation, reputation express the net outcome of the combination of all stakeholders' perception. The identity of a company refers more to the values and ethical or management principles management and employees apply and demonstrate to the other stakeholders. Even if recognised as different (Gray\& Balmer, 1998), image and reputation are sometimes used interchangeably but it can be admitted that these concepts are different in essence. Walker (2010) enhances the difference between identity, image and reputation by systematically reviewing corporate reputation literature from over twenty-seven (27) years as shown in table 1. 
Table 1 : Comparing Organizational Identity, Image, and Corporate Reputation

\begin{tabular}{|c|c|c|c|}
\hline & Organizational identity & Organizational image & Corporate reputation \\
\hline $\begin{array}{l}\text { Stakeholders: Internal or } \\
\text { external }\end{array}$ & Internal & External & Internal and external \\
\hline Perceptions: Actual or desired & Actual & Desired & Actual \\
\hline $\begin{array}{l}\text { Emanating from inside or } \\
\text { outside the firm }\end{array}$ & Inside & Inside & Inside and outside \\
\hline $\begin{array}{l}\text { Positive or negative perception } \\
\text { of the firm possible }\end{array}$ & Positive or negative & Positive & Positive or negative \\
\hline Relevant question & $\begin{array}{l}\text { 'Who/what do we } \\
\text { believe we are?'a }\end{array}$ & $\begin{array}{l}\text { 'What/who do we } \\
\text { want others to } \\
\text { think we are?' }\end{array}$ & $\begin{array}{l}\text { 'What are we seen } \\
\text { to be?'b }\end{array}$ \\
\hline
\end{tabular}

aWhetten (1997: 27)

${ }^{b}$ Balmer and Greyser (2006)

Source: Walker (2010)

Feldman et al. (2014) have presented Walker (2010) questions linked to each concept:

- For "Identity", the question is: Who / what do we believe we are?

- For "Image", the question is: What / who do we want others to think we are?

- And for "Reputation", the question is: What are we seen to be?

The answers to these three (03) questions cannot be the same. Identity, image, and reputation should then be totally different concepts playing distinct roles in an organisation. Organisational identity clearly tends to refer to internal stakeholders alone, and organisational image to external stakeholders alone, while corporate reputation overtly refers to both internal and external (Walker, 2010).

\subsection{Corporate reputation definitional landscape}

Practitioners from many industries and scholars from various disciplines have proposed their definition in line with respective contexts. Each approach brings a meaningful added value to the concept of corporate reputation making it clearer. Adversely, the richness of contents in reputation concepts makes problematic for scholars and practitioners to unify their numerous understandings (Bălan; 2015, Barnett et al., 2006). Fombrun (1997) is one of the pioneers. The author defines reputation as the overall valuation of an organisation by its stakeholders which is derived from their net affective feedbacks. This definition highlights only affective reactions. Schwaiger (2004) found unclear why cognitive components are not included. Gray and Balmer (1998) see corporate reputation as an assessment of a company's attributes, what seems completely cognitive. Alternatively, Hall (1992) consider both cognitive and affective components by defining corporate reputation as the knowledge and the emotions held by individuals. This certainly means that behind "reputation" we may have not only emotions or feelings that link us to an organisation but also a logic or a result based on our assessment of its characteristics, identity, products, etc. Barnett et al. (2006:30) discussing the definitional landscape, made an exhaustive inventory of "corporate reputation" definitions from a total of 49 unique sources. From this rich list of statements, Barnett et al. (2006) found that there is no commonly accepted definition. In fact, there are a lot of unique statements and wide difference between the proposed meaning and definition. Globally Barnett et al. (2006) classified the various definitional statements into three (03) different clusters of meaning: state of awareness, assessment and asset. Awareness: Reputation is a state of awareness when it is considered stakeholders have a general awareness of a company without an experience and then made no judgement. This is "perception" which may include perceptual or collective representation and emotion from the stakeholders (Barnett et al., 2006).

Assessment: Reputation becomes an assessment when stakeholders judge the organisation. This comes above a simple awareness and stakeholders are involved in assessment of the company. You can only assess what you are aware of. This cluster includes references to an estimate, judgement, evaluation or gauge which are all four similar in meaning. Esteem, beliefs and opinions also refer to assessment. Assessment is mostly used defining corporate reputation than Awareness and Asset (Barnett et al., 2006). 
Asset: Whether reputation is good or not, it affects the whole organisation in several ways (Adeosun \& Ganiyu, 2013). When good, it is then an advantage, something of value and consequence to the organisation. Most definitions framing reputation as "awareness" or "assessment" do not consider it as an asset. Asset refers to resource, intangible asset, financial or economic asset (Barnett et al., 2006).

At the end, Barnett et al. (2006) offered the following definition: "Observers' collective judgments of a corporation based on assessments of the financial, social, and environmental impacts attributed to the corporation over time".

This definition supposedly includes all the three clusters meaning identified by the authors but reference to "asset" may seem less clear. "Observers' collective judgement" consider the awareness and the assessment meaning and "environmental impacts attributed to the corporation over time" represent the "asset". Globally, it is hard to see "impacts" as an "asset", but the researcher thinks "impacts" can help build or enhance an asset. Considering this definition, "asset" may be negative or positive. If the global impacts are positive, they will build a good reputation thus an asset for the organisation, but if impacts are negative, bad reputation will derive with all its possible business consequences. Walker (2010) accentuates that corporate reputation may be either positive or negative. In relation to Barnett et al. (2006) definition, Shirin and Kleyn (2017) mentioned that the clusters are interrelated: awareness may lead to assessment and if assessment is encouraging, the customer's experience may become an asset to the organisation. It is then deductible that positive stakeholders' experience builds reputation. It also means there is no room for reputation where assessment brings negative results.

Chun (2005) identifies three school of thought regarding corporate reputation: evaluative, impressional, and relational. The "relational" school considers different stakeholders with different expectations from the organisation while "evaluative" and "impressional" focus on single stakeholder interests. The evaluative school, in line with the "assessment" cluster meaning of Barnett et al. (2006), appraises financial value or financial and strategic performance of the organisation. Here investors or managers influence the perception. The impressional school sees reputation as the overall impression of an organisation. Reputation is then defined by corporate image, customer's views, favourableness of media coverage. This seems close to Barnett et al. (2006) "awareness" cluster meaning. The relational school involves gaps between internal and external stakeholders' views (Chun, 2005).

Although there are numerous similarities in the definitional approaches, corporate reputation remains a concept hard to define with a unanimous view from scholars and practitioners. To the researcher's knowledge, there are limited research that explicitly focus on banks' corporate reputation. Although there are peculiarities in bank industry, corporate reputation has not been defined in a different way for banks. This work then globally follows Barnett et al. (2006) approach and the researcher sees "Corporate reputation as an asset built over time by organisation stakeholders' collective expectations, perceptions and conclusive experiences".

\section{Importance of reputational risk in banking industry}

Academics and professionals unanimously agree corporate reputation is predominantly important for banks because of the nature of services they provide, which are not only intangible but are also subject to trust (Trotta \& Cavallaro, 2012). Settling the reputational risk concept, the Basel Committee on Banking Supervision (2009) indicates that it depends not only on banks internal factors but also on some important externals factors. "Reputational risk can be defined as the risk arising from negative perception on the part of customers, counterparties, shareholders, investors or regulators that can adversely affect a bank's ability to maintain existing, or establish new, business relationships and continued access to sources of funding (eg through the interbank or securitisation markets)" (BCBS, 2009:19). The Basel II proposed regulations enhancement, following subprime crisis and multiple banks crisis globally highlighted the need for banks to seriously consider reputational risk. In fact, financial services are special because they mostly deal with other people's money (Walter \&Pinedo, 2013). Any problem arising at any level can trigger grave external costs. "Reputational risk is particularly damaging for banks since the nature of their business requires maintaining the confidence of depositors, creditors and the general marketplace" (BCBS, 1997:22). Without a sound reputation, a bank or any other financial institution will hardly succeed. 


\section{Corporate reputation dimensions and attributes}

Many authors have attempted to categorize the different constituents of corporate reputation. There is a proliferation of various parameters defined and methods to measure corporate reputation. Modern understanding of corporate reputation depicts it as a multidimensional construct (Agarwal, Osiyevskyy\& Feldman, 2015). Schwaiger (2004) sees corporate reputation as an attitudinal construct which includes two dimensions: affective and cognitive. The affective dimension refers to emotions held by individuals while cognitive dimension is based on attributes assessment. The author made a comprehensive desk research that shows that existing reputation measurement tools are based on some key categories. As a result, the author identified three categories: (a) Fair attitude towards competitors; (b) Transparency and openness and (c) Credibility. Alternatively, Keller and Aaker (1998) have used Keller's three dimensions of "corporate credibility": (a) expertise, (b) trustworthiness and (c) likability to evaluate bonds with successful brand extensions. In Schwaiger (2004) categorisation, it is possible to bind together (b) Transparency and openness and (c) Credibility to create Keller's (1998) (b) trustworthiness. Keller's approach may look more extended than the categorisation of Schwaiger (2004).

From the reviewed literature, corporate reputation dimensions and attributes vary from one approach to another, from a model to another.

\section{Existing reputation models}

Among the existing models, the reputation Quotient (Fombrun, 2000) six (06) dimensions and twenty (20) attributes seem more complete, but Trotta and Cavallaro (2012) 5R model encompasses dimensions and items that seem more suitable for banking industry. A summary of the most known qualitative models is proposed by Trotta and Cavallero (2012) and details are available in table 2 below:

Table 2: Qualitative models' summary

\begin{tabular}{|c|c|c|c|}
\hline $\begin{array}{l}\text { Measures of } \\
\text { reputation }\end{array}$ & Who is surveyed & Dimensions & Items for Dintensions \\
\hline $\begin{array}{l}\text { Fortume's } \\
\text { (WMAC) }\end{array}$ & $\begin{array}{l}\text { Senior executives, directors and } \\
\text { financial analysts (about } 4,000 \text { ) }\end{array}$ & $\begin{array}{l}\text { Innovation, Quality of } \\
\text { management, Long-term } \\
\text { investment value, Social } \\
\text { responsibility, People } \\
\text { management, Quality of } \\
\text { products, Financial soundness, } \\
\text { Use of corporate assets and } \\
\text { Global competitiveness. }\end{array}$ & - \\
\hline
\end{tabular}

Emotional appeal (Feeling good about, Trust, Admire and Respect); Products and services (High Quality, Innovative, Value for Money, Stands Behind);

Emotional appeal, Products Workplace Environment (Rewards Employees Fairly, and services, Financial

Several stakeholders: general

Reputation public, customers, employees, Quotient (RQ) suppliers and investors etc (over 30,000 in $1^{\circ}$ stage) performance, Vision and leadership, Workplace environment and Social responsibility.
Good Place to Work, Good Employees); Financial

Performance (Outperforms Competitors, Record of Profitability, Low Risk Investment, Growth Prospects); Vision and Leadership (Market Opportunities, Excellent Leadership, Clear Vision for the Future); Social Responsibility (Supports Good Causes, Environmental Responsibility, Community Responsibility)

\begin{tabular}{|c|c|c|c|}
\hline $\begin{array}{l}\text { RepTrak } \\
\text { system }\end{array}$ & $\begin{array}{l}\text { Key stakeholders: advocacy } \\
\text { groups/NGOs, regulators, } \\
\text { governament officials, media, } \\
\text { business leaders, community } \\
\text { leaders, opinion elites, analysts, } \\
\text { customers, employees, business } \\
\text { partners and investors etc (over } \\
60,000 \text { for Global RepTrak Pulse) }\end{array}$ & $\begin{array}{l}\text { Products/Services, Innovation, } \\
\text { Workplace, Governance, } \\
\text { Citizenship, Leadership and } \\
\text { Performance. }\end{array}$ & $\begin{array}{l}\text { Products/Services (High quality, Value for Money, } \\
\text { Stands Behind, Meet Customers Needs); Innovation } \\
\text { (Innovative, First to Market, Adapts Quickly to Change), } \\
\text { Workplace (Rewards Employees Fairly, Employee well- } \\
\text { being, Offers Equal Opportunities); Gorernance (Open } \\
\text { and Transparent, Behavers Ethically, Fair in the way it } \\
\text { does Business); Citizenship (Enviromentally } \\
\text { Responsible, Supports Good Causes, Positive Influence } \\
\text { on Society); Leadership (Well Organized, Appealing } \\
\text { Leader, Excellent Management, Clear Vision for its } \\
\text { Future) and Performance (Profitable, High Performing, } \\
\text { Strong Growth Prospects). }\end{array}$ \\
\hline
\end{tabular}

Others qualitative models include:

- African reputation Index recently launched in 2017 (South Africa)

- Fortune's World Most Admired Companies (WMAC) 
- RepTrack by Reputation Institute

- Consumer Reputation Index (CRI) proposed by Feldman et al. (2014).

There are also quantitative approaches to measuring corporate reputation and comprise:

- Marketing approach

- Event study analysis

- Intellectual capital approach

- Accounting approach.

They look to overcome the weaknesses of the qualitative approaches. The only model identified across the reviewed literature addressing banks is 5R model from Trotta and Cavallaro (2012). The model is designed specifically for Italian banks, and features five dimensions as follow: Relationship with external and internal stakeholders, Results, Responsibility, Role and Regulatory compliance. These five dimensions are linked with some items for corporate reputation appraisal as stated in Table 3.

Table 3: A proposal to assess bank's reputation: Five "R's" Model

\begin{tabular}{|c|c|c|c|c|c|}
\hline $\begin{array}{c}\text { Key } \\
\text { Dimensions }\end{array}$ & Role & Responsibility & $\begin{array}{c}\text { Relationship } \\
\text { (with internal \& } \\
\text { external } \\
\text { stakeholders) }\end{array}$ & Results & $\begin{array}{l}\text { Regulatory } \\
\text { Compliance }\end{array}$ \\
\hline
\end{tabular}

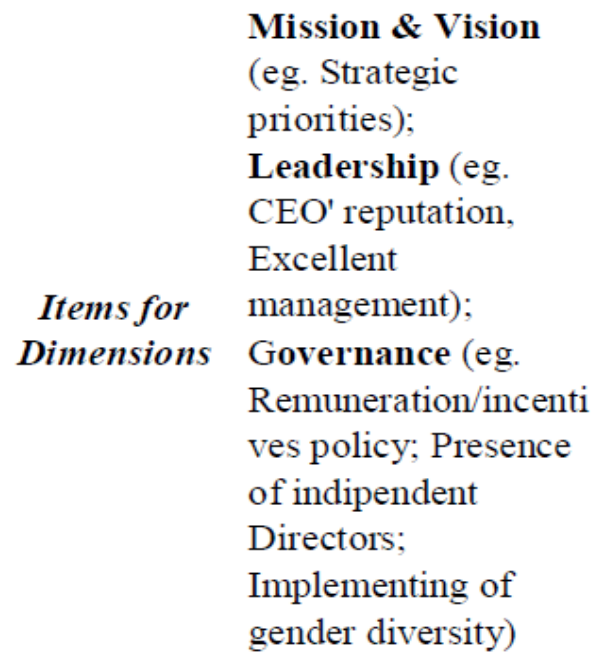

CSR policy;
Ethical
Behaviour;
Workplace
Environment
(eg. employee
satisfaction,
employees'
expertise)

Informative
transparency
with
stakeholders;
Disclosure;
Trust \&
Confidence (eg.
future safety of
deposits and
investments)

Product \&

Services (eg. Risk

quality of

deposits,

Management;

investments;

Antitrust ;

), Financial Management;

Performance Anti Money

(eg. profitability, Laundering

growth

Policy

perspective)

Implementing of

\footnotetext{
Who/What is Senior executives; Directors and financial Analysts; Regulators \&

Who/What is Supervisors, Media, Customers, Employees, Shareholders \& Investors,
surved surveyed Rating Agencies, other Banks and competitors

Documents'

Analysis
}

Source: Trotta \& Cavallaro (2012)

The authors argued "responsibility" and "regulatory compliance" are the main drivers of banks' corporate reputation. Fundamentally, Trotta and Cavallaro (2012) index combines social ranking methodology with an analysis of the "sensible documentation by assigning a negative ranking in case of sanctions, corrective measure or special administrative procedure triggered by Authority inspections and controls". According to the authors appraising Italian banks, sensible documentation includes "Bank of Italy's supervisory bulletin, annual report of Antitrust, UIF's report etc".

\section{Corporate reputation in African banks: an empirical study}

\subsection{Methodological overview}

This research study included desk research and In-depth interviews (IDI, Qualitative approach, primary research). Desk research also refers as secondary research or secondary data analysis which is an "analysis of data that was collected by someone else for another primary purpose" (Johnston, 2014). 
Desk research provides the researcher a practical option in response to limited time and resources. This approach also offers the advantage of cost-effectiveness (Dale, Arbor, \& Procter, 1988) since the researcher has not spent money to get access to this data. Insights from secondary sources were the foundations for the qualitative stage of the study: In-depth Interviews. Qualitative research methods offer ways to discover and analyse patterns, attributes, phenomena, practices, and experiences in sociocultural worlds (Moen \&Middelthon, 2015)."In-depth interviewing is the most common qualitative research method" (Morris, 2015). Time limitation and research budget have been the major reason for using in-depth interviews instead of focus groups. Focus groups need to gather people from various profile in regard to the addressable target group and may require complex and unaffordable logistics. And the researcher thinks that group interaction was not required for the relevancy of the work.

In-depth interviews are found more appropriate to the research because it permitted a deep one to one discussion and offers a richness of insights (Morris, 2015). "IDIs provide the best opportunity to explore decisions and compare differences and similarities among reference group members" (Azzara, 2010). In total, six (06) interviews were conducted by the researcher himself using a developed interview guide, in Cotonou (Benin), February 2018. All the respondents were in a top management role, with over ten years of experience as a banker or as a bank customer. They are either Managing Director or Chief Executive Officer, or Head of Finance, Head of Risk,Head of Corporate Banking, Head Compliance.

\subsection{Findings analysis and discussions}

When discussing the relevant dimensions and attributes of corporate reputation in West Africa Monetary Union, considering the interviewees views, the following eight categories or dimensions (table 4), with corresponding perceived weight, seem to be the more significant in the WAMU banking industry:

Table 4: Dominant dimensions of corporate reputation in WAMU banks

\begin{tabular}{|l|l|l|}
\hline $\mathbf{N}^{\circ}$ & Dimension & Perceived average weight \\
\hline 1 & Governance & $25.83 \%$ \\
\hline 2 & Relationship with stakeholders & $24.17 \%$ \\
\hline 3 & Regulatory compliance & $22.50 \%$ \\
\hline 4 & Performance & $10.83 \%$ \\
\hline 5 & Products \& Services & $8.33 \%$ \\
\hline 6 & Brand \& Likability & $3.33 \%$ \\
\hline 7 & Vision and leadership & $3.33 \%$ \\
\hline 8 & Social Responsibility & $1.67 \%$ \\
\hline
\end{tabular}

There is a variety of dimensions and attributes of corporate reputation identified across the literature for suggested models (Fombrun et al., 2000; Chun, 2005; Schwaiger, 2004). Many authors proposed drivers that seem inadequate and not complete for the financial industry, especially for banks because of their peculiarities. As a matter of fact, banks are extremely regulated, and information asymmetries issues, trust, systemic risks are specific factors that shape the way reputation can be understood and measured (Trotta and Cavallaro, 2012). Fombrum et al. (2000) Reputation Quotient suggest twenty items for six dimensions known as: Emotional Appeal, Products and Services, Vision and Leadership, Workplace Environment, Financial Performance, Social Responsibility. These dimensions were suggested for assessing the reputation of any organisation regardless of its sector. Specifically, for banks, Trotta and Cavallaro (2012) proposed 5R model which has five key dimensions as follow: Role, Responsibility, Relationship, Results, Regulatory compliance.

In the thematic findings, it is presented that most relevant dimensions in Africa are: Governance, Relationship with stakeholders, Regulatory compliance, Products \& Services, Performance and others minors that may be grouped as "Image" (Brand \& Likability, Vision and Leadership, Social Responsibility). The interviewees opinions confirm partially both Fombrun et al. (2000) and Trotta and Cavallaro (2012) theories. Emotional appeal is not considered in Trotta and Cavallaro and has been also found less important in the thematic analysis. Corporate Social Responsibility is considered in both theories but is seen as a minor area of reputational risk from the study. It then seems that the affective component of corporate reputation has less importance than its cognitive component in Africa banking industry. 
This does not confirm Schwaiger (2005) theory seeing corporate reputation as an attitudinal construct which includes two dimensions: affective and cognitive. Then, reputation in African banks seems to have less to do with emotions held by individuals, but much with attributes assessment. From the analysis, the identified dimensions are close to those of Trotta and Cavallaro (2012) model but strongly differ in terms of relative importance. Interviewee's opinions with their eight dimensions were critically analysed and it is found that their views may be reorganised to cover six key resulting dimensions listed as follow in order of importance:

1. Governance (Ownership structure, Corporate strategy, Human capital etc)

2. Relationship with stakeholders (TCF rules, relationship with corresponding banks, financial partners etc)

3. Regulatory compliance (risk management, central bank regulations etc.)

4. Products \& Services (Pricing, product adequacy, etc)

5. Performance (record of profitability, growth perspective etc)

6. Image (Brand \& Likability, Leadership, Social Responsibility).

As the key stakeholder groups identification is essential for assessing appropriately corporate reputation dimensions for banks (Trotta and Cavallaro, 2012), the researcher has listed in Appendix all the relevant six (06) dimensions and forty (40) attributes from the study with corresponding source of data or stakeholders to be surveyed for measurement. In Trotta and Cavallaro 5R model, Governance (Role) plays an important role as well along with Corporate Social Responsibility, but interviewees have shown tiniest attention to social responsibility as CSR do not yet seem to be well incorporated in African customers' culture. This help the researcher understand that what is relevant in a Western country could not systematically apply to an African country even though all the banks are complying to Basel rules.

\section{Recommendations: A framework proposal (AFRIX)}

The analysis evidences the relevance of the identified dimensions and attributes, and their relative importance in measuring and managing corporate reputation in African banking industry. Taking into account African banking industry features we identified with relative weight, the definition of reputational risk given by regulators (BCBS, 2009), the researcher proposes a model focused on African banking system named: African Financial Institutions Reputation Index (Afrix) classifying the following six (06) dimensions: Governance, Relationship, Regulatory compliance, Products and services, Performance and Image. AFRIX's framework is presented in Figure 3 below:

Figure 2: AFRIX Reputational Model

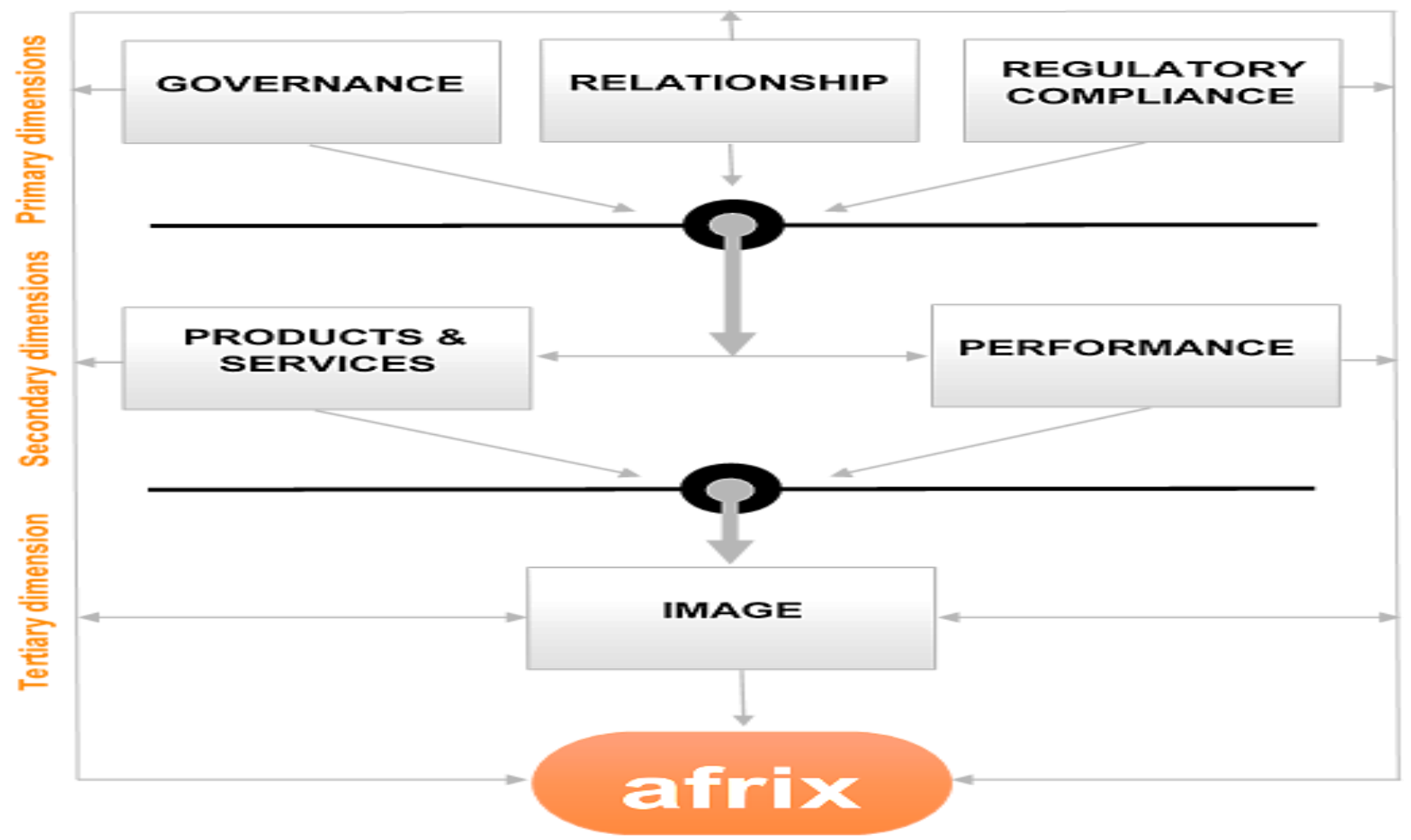


The linked attributes for each of the six (06) dimensions are proposed in appendix. The researcher also included in appendix the stakeholders group for the assessment of each dimension. Regarding managing reputational risk in African banks, the findings suggest that banks should focus all their efforts on the three primary dimensions which are: Governance, Relationship and Regulatory compliance which are also major elements in Trotta and Cavallaro model. Good "Products \& Services" and "Performance" may naturally follow. The researcher conceptualises from the study that if a bank embarks knowledgeable, trustworthy, and reputable human capital, the bank will be very easily lead it in an adequate direction (corporate strategy, culture) using a savvy relationship with all its stakeholders (TCF's 6 pillars, staff, corresponding banking, etc.) while meeting applicable regulations. Subsequently, adequate "products and services" will be proposed to customers with assurance of profitability (performance). This explains why "Products \& Services" and "Performance" are classified as secondary dimensions. They can be seen as an outcome of the three major dimensions. In a bank, the quality of the three major dimensions can purposely define the quality of the "Products \& Services" and "Performance". Performance is based on the suitability of product and services the bank is offering to its customers. All these lead to image (tertiary dimension) which entails how the bank is perceived in terms of likability and leadership on the market place and social responsibility. For example, getting engaged with the community to support development may not be possible if a bank is not profitable. In Africa, very few banks seem to support their community as argued by the interviewees. All the six dimensions individually contribute to the calculation of the AFRIX.

\subsection{Calculation of AFRIX}

AFRIX is an index (ranging from 0.0 to 5.0) calculated based on attributes scored by stakeholders group using a six (06) point scale as proposed by Feldman et al. (2014): Absolutely Disagree (0), Disagree Very Much (1), Somewhat Disagree (2), Somewhat Agree (3), Agree Very Much (4), Absolutely Agree (5). The data for the measurement of AFRIX is from two sources:

1. Secondary sources are used for performance and regulatory (financial statements published, Central banks reporting, supervisory board reporting, monitoring compliance, applied sanctions to banks etc) available from website and newspapers.

2. Primary data collected from relevant stakeholders about banks operating in Africa using a semi structured questionnaire on a quarterly basis. AFRIX will work like a barometer. The data from secondary sources and primary sources will be computed to calculate the index.

\subsection{Interest of AFRIX Model}

AFRIX is an attempt to improve Trotta and Cavallaro 5R model with suitability for African banks. AFRIX will not only measure corporate reputation but is also a management tool for reputational risk. A bank can then identify its weaknesses based on how it scored on the various dimensions. A website could be developed to publish a rating and ranking in order to better inform customers. In fact, one of the biggest issues in Africa banking system is a very poor customer literacy. The website can provide up-to-date information to all the customers in order to help them make better purchase decision, specifically making the good and conscious choice while selecting their bank.

\section{Limitations and future research}

When conducting the study, the researcher faced a few limitations as follow:

1. Only six (06) IDI were conducted in Benin, and none in the other African countries. This is a major limitation to the study as the results may not reflect the actual situation of whole continent.

2. The study has not been customer centric. Because of time and budget constraints, the methods et sample size utilised are very limitative. Focus Groups with customers' groups we identified could have help us gain a deeper understanding of the reputation concept in Africa, from a customer perspective.

3. AFRIX model is under development but ambitions to become a strong managerial tool for efficient outcome both for African banks and their customers.

Future research may explore the opportunity to cover a wider sample in several African countries. For qualitative approach, IDI may be used for top banking industry executives and corporate and high value private customers. FGD can be used for retail banking customers. Furthermore, to permit an accurate measurement of corporate reputation using AFRIX model, a quantitative survey may be utilized to statistically validate the identified dimensions and attributes with corresponding weight. Statistical methods can be developed to calculate AFRIX. 
It may be interesting to investigate how reputational risk is managed in African banks, and how AFRIX may help improve banks competitiveness, having reputational risk incorporated in the whole risk management strategy along with the other risks that are currently considered in Basel II regulations (risk of credit, market risk, operational risk).

\section{References}

Adcomm Media (2017). Magna Carta launch Africa Reputation Index. Retrieved 31.01.2018 from https://www.adcomm.co.za/recent-news/643-magna-carta-launch-africa-reputation-index.

Adeosun, L.P.K. \&Ganiyu, R.A. (2013). Corporate Reputation as a Strategic Asset. International Journal of Business and Social Science, 4(2).

Agarwal, J., Osiyevskyy, O., \& Feldman, P.M. (2015). Corporate Reputation Measurement: Alternative Factor Structures, Nomological Validity, and Organizational Outcomes. Journal of Business Ethics. DOI: 10.1007/s10551-014-2232-6.

Azzara, C. (2010). Qualitatively Speaking: The focus group vs. in-depth interview debate. Retrieved 18.02.2018 from https://www.quirks.com/articles/qualitatively-speaking-the-focus-group-vs-in-depth-interviewdebate

Babić-Hodovića, V., Mehića, E., \&Arslanagić, M. (2011). Influence of Banks' Corporate Reputation on Organizational Buyers Perceived Value. Paper presented at the 7th International Strategic Management Conference, Sarajevo.

Bălan, D.A. (2015). Bridging the Gap in Defining Corporate Reputation: An Extensive Literature Review. Retrieved 15.01.2018 from http://cis01.central.ucv.ro/revistadestiintepo litice/files/numarul46_20 15/7 \%20Bridging\%20t he\%20Gap\%20in\%20Defining\%20Corporate\%20Reputation...\%20pp.\%2073-83.pdf

Barnett, M.L., Jermier, J.M. \& Lafferty, B.A. (2006). Corporate Reputation: The Definitional Landscape. Corporate Reputation Review. doi: 10.1057/palgrave.crr.1550012

Basel Committee on Bank Supervision, BCBS. (1997). Core Principles for Effective Banking Supervision. Retrieved 18.01.2018 from https://www.bis.org/publ/bcbsc102.pdf

Basel Committee on Banking Supervision, BCBS. (2009). Proposed enhancements to the Basel II framework. Retrieved 14.01.2018 from https://www.bis.org/publ/bcbs150.htm

Babbie, E. (2011). The Basics of Social Research (Fifth Edition). USA: Wadsworth, Cengage Learning.

Baybars-Hawks, B., \&Samast, O. (2013). New Challenges, New Opportunities: Interdisciplinary Perspectives on Reputation Management. Turkey: Reputation Management Institute.

Chun, R. (2005). Corporate reputation: Meaning and measurement. International Journal of Management Reviews, 7(2), 91-109.

Deloitte (2016). Your essential guide to de-risking Africa: Unlocking the value in Africa. Retrieved 27.02.2018 from

https://www2.deloitte.com/content/dam/Deloitte/za/Documents/risk/ZA_Derisking\%20Africa\%20Brochu re_FINAL_digi_spreads.pdf

Feldman, P. M., Bahamonde, R. A. \& Bellido, I. V. (2014). A new approach for measuring corporate reputation. Revista de Administração de Empresas (RAE). 54(1). 53-66.

Fombrun, C. J., Gardberg, N. A., \& Sever, J. W. (2000). The reputation quotient: A multi-stakeholder measure of corporate reputation. The Journal of Brand Management, 7(4), 241-255.

Fombrun, C.J. \& Van Riel, C (1997). The Reputational Landscape. Corporate Reputation Review, 1(1/2), 5-13

Gray, E. R., \& Balmer, J.M.T. (1998). Managing Corporate Image and Corporate Reputation. Long Range Planning, 31(05), pp.695-702.

Greenspan, A. (1999). Maintaining Economic Vitality. Remarks by Chairman Alan Greenspan. The Federal Reserve Board. Retrieved 13.01.2018 from https://www.federalreser ve.gov/boarddocs/spe eches/199 9/19990908.htm

Hall, R. (1992). The Strategic Analysis of Intangible Resources. Strategic Management Journal, 13(), pp.135-144.

Keller, K.L. \& Aaker, D.A. (1998). Corporate level marketing: the impact of credibility marketing on brand extensions. Corporate Reputation Review, 1(4), 356-378. 
Moen, K. \&Middelthon, A. (2015). Qualitative Research Methods in PetterLaake, P., Benestad, B. H., and Olsen, B. R. Research in Medical and Biological Sciences ( $2^{\text {nd }}$ Ed.). https://doi-org.salford.idm.oclc.org/10. 1016/B978-0-1 2-799943-2.00017-3

Morris, A. (2015). A practical introduction to In-Depth Interviewing. London: SAGE Publications.

Reputation Institute (2016). 2016 Global RepTrak®100: The World's Most Reputable Companies. Retrieved 14.01.2018 from https://www.rankingthebrands.com/PDF/Global\% 20RepTrak \%2 0100\%20R eport\%202 016,\%20Reputation\%20Institute.pdf

Saldaña, J. (2009). The coding manual for qualitative researchers. London: Sage Publications Ltd.

Schwaiger, M. (2004). Components and parameters of corporate reputation: an empirical study. Schmalenbach Business Review, 56(1), $46-71$.

Stansfield, G. (2006). Some Thoughts on Reputation and Challenges for Global Financial Institutions. The Geneva Papers on Risk and Insurance - Issues and Practice, 31(3), 470-479.

Trotta, A. \& Cavallaro, G. (2012). Measuring corporate reputation: a framework for Italian banks. International Journal of Economics and Finance Studies, 4(2).

Walker, K. (2010). A Systematic Review of the Corporate Reputation Literature: Definition, Measurement, and Theory. Corporate Reputation Review DOI:10.1057/crr.2009.26

Appendix: WAMU Banks Corporate reputation dimensions \& Attributes $\mathrm{S}=$ Secondary source; $\mathrm{P}=$ Primary Source

\begin{tabular}{|c|c|c|c|}
\hline NO & Dimensions \& Attributes & $\begin{array}{l}\text { Type of } \\
\text { data }\end{array}$ & Source / Stakeholders' groups surveyed \\
\hline I & Governance & & \\
\hline 1.1 & Ownership structure & $\mathrm{S}$ & $\begin{array}{l}\text { Bank website, Internet, Central bank website, } \\
\text { Referenced newspapers or journal etc. }\end{array}$ \\
\hline 1.2 & $\begin{array}{l}\text { Reputation and pedigree of board } \\
\text { members }\end{array}$ & $\mathrm{S} / \mathrm{P}$ & $\begin{array}{l}\text { Internet, Social Networks (Education, Years of } \\
\text { Experience, eventual scandals etc), Survey } \\
\text { (Interviewees opinions etc) }\end{array}$ \\
\hline 1.3 & $\begin{array}{l}\text { Overall qualification of the banks } \\
\text { executives }\end{array}$ & $\mathrm{S} / \mathrm{P}$ & $\begin{array}{l}\text { Internet, Social Networks (Education, Years of } \\
\text { Experience, eventual scandals etc), Survey } \\
\text { (Interviewees opinions etc) }\end{array}$ \\
\hline 1.4 & Quality of corporate culture & $\mathrm{S} / \mathrm{P}$ & $\begin{array}{l}\text { Bank website, Internet search, social networks; } \\
\text { Survey (Interviewees opinions etc) }\end{array}$ \\
\hline 1.5 & $\begin{array}{l}\text { Quality of Corporate strategy } \\
\text { management (vision, missions, strategic } \\
\text { approach, plans etc) }\end{array}$ & $\mathrm{S} / \mathrm{P}$ & $\begin{array}{l}\text { Bank website, Internet search, social networks; } \\
\text { Survey (Interviewees opinions etc) }\end{array}$ \\
\hline 1.6 & $\begin{array}{l}\text { Quality of knowledge management } \\
\text { system }\end{array}$ & $\mathrm{S} / \mathrm{P}$ & $\begin{array}{l}\text { Bank website, Internet search, social networks; } \\
\text { Survey (Interviewees opinions etc) }\end{array}$ \\
\hline 1.7 & Risk management policy & $\mathrm{S} / \mathrm{P}$ & $\begin{array}{l}\text { Bank website, Internet search, social networks; } \\
\text { Survey (Interviewees opinions etc) }\end{array}$ \\
\hline II & Relationship & & \\
\hline 2.1 & Commitment to a strict delay policy & $\mathrm{P}$ & Customers (Corporate, SME Individuals) \\
\hline 2.2 & Appropriate information policy & $\mathrm{P}$ & Customers (Corporate, SME Individuals) \\
\hline 2.3 & Suitability of advisory & $\mathrm{P}$ & Customers (Corporate, SME Individuals) \\
\hline 2.4 & Transparency & $\mathrm{P}$ & Customers (Corporate, SME Individuals) \\
\hline 2.5 & Empathy & $\mathrm{P}$ & Customers (Corporate, SME Individuals) \\
\hline 2.6 & Non-disclosure of Customer privacy & $\mathrm{P}$ & Customers (Corporate, SME Individuals) \\
\hline 2.7 & Tiers-1 correspondent banks network & $\mathrm{S} / \mathrm{P}$ & $\begin{array}{l}\text { Bank website, Internet, Investigations; Customers } \\
\text { (Corporate, SME Individuals); }\end{array}$ \\
\hline III & Regulatory Compliance & & \\
\hline 3.1 & Non-involvement in political activities & $\mathrm{S} / \mathrm{P}$ & News, investigations, customers (survey) \\
\hline 3.2 & $\begin{array}{l}\text { Anti-Money Laundering (AML) } \\
\text { compliance }\end{array}$ & $\mathrm{S}$ & $\begin{array}{l}\text { Banks' professional bodies, Official regulatory } \\
\text { board reports, international reports, news, sanctions } \\
\text { from central bank etc. }\end{array}$ \\
\hline
\end{tabular}




\begin{tabular}{|c|c|c|c|}
\hline 3.3 & Regulatory Level of NPL & $\mathrm{S}$ & $\begin{array}{l}\text { Banks' professional bodies, Official regulatory } \\
\text { board reports, international reports, news, etc. }\end{array}$ \\
\hline 3.4 & $\begin{array}{l}\text { Regulatory Capital Adequacy Ratio } \\
\text { (solvency ratio) }\end{array}$ & $\mathrm{S}$ & $\begin{array}{l}\text { Banks' professional bodies, Official regulatory } \\
\text { board reports, international reports, news, etc. }\end{array}$ \\
\hline 3.5 & Regulatory minimum capital ratio & $\mathrm{S}$ & $\begin{array}{l}\text { Banks' professional bodies, Official regulatory } \\
\text { board reports, international reports, news, etc. }\end{array}$ \\
\hline 3.6 & Regulatory liquidity coverage ratio & $\mathrm{S}$ & $\begin{array}{l}\text { Banks' professional bodies, Official regulatory } \\
\text { board reports, international reports, news, etc. }\end{array}$ \\
\hline 3.7 & $\begin{array}{l}\text { Compliance with all central bank } \\
\text { regulations and local laws }\end{array}$ & $\mathrm{S} / \mathrm{P}$ & $\begin{array}{l}\text { Banks' professional bodies, Official regulatory } \\
\text { board reports, international reports, news, etc. } \\
\text { Customers (survey) }\end{array}$ \\
\hline IV & Products and services & & \\
\hline 4.1 & Product and services adequacy & $\mathrm{P}$ & Customers (Corporate, SME, Individuals) \\
\hline 4.2 & Innovation & $\mathrm{P}$ & Customers (Corporate, SME, Individuals) \\
\hline 4.3 & Value for money & $\mathrm{P}$ & Customers (Corporate, SME, Individuals) \\
\hline 4.4 & Compliance & $\mathrm{P}$ & Customers (Corporate, SME, Individuals) \\
\hline 4.5 & $\begin{array}{l}\text { Availability and accessibility of products } \\
\& \text { services }\end{array}$ & $\mathrm{P}$ & Customers (Corporate, SME, Individuals) \\
\hline 4.6 & Efficient Electronic facilities & $\mathrm{P}$ & Customers (Corporate, SME, Individuals) \\
\hline $\mathbf{V}$ & Performance & & \\
\hline 5.1 & $\begin{array}{l}\text { Record of profitability (Net Banking } \\
\text { Income) }\end{array}$ & $\mathrm{S}$ & $\begin{array}{l}\text { Banks' professional bodies, Official regulatory } \\
\text { board reports, international reports, news, } \\
\text { investigations etc. }\end{array}$ \\
\hline 5.2 & Reference by key Institutions & $\mathrm{S} / \mathrm{P}$ & $\begin{array}{l}\text { Investigations, news, Internet search, journals \& } \\
\text { magazines etc. }\end{array}$ \\
\hline 5.3 & Publications in news and journals & $\mathrm{S} / \mathrm{P}$ & $\begin{array}{l}\text { Investigations, news, Internet search, journals \& } \\
\text { magazines etc. }\end{array}$ \\
\hline 5.4 & Growth perspective & $\mathrm{P}$ & $\begin{array}{l}\text { Investigations, news, Internet search, journals \& } \\
\text { magazines etc. }\end{array}$ \\
\hline 5.5 & ISO certified & $\mathrm{S} / \mathrm{P}$ & $\begin{array}{l}\text { Investigations, news, Internet search, journals \& } \\
\text { magazines etc. }\end{array}$ \\
\hline 5.6 & $\begin{array}{l}\text { Listing or notation as Investment grade } \\
\text { institution }\end{array}$ & $\mathrm{S} / \mathrm{P}$ & $\begin{array}{l}\text { Investigations, news, Internet search, journals \& } \\
\text { magazines etc. }\end{array}$ \\
\hline VI & Image & & \\
\hline 6.1 & Trustworthiness & $\mathrm{P}$ & Customers (Corporate, SME, Individuals) \\
\hline 6.2 & Brand recognition & $\mathrm{P}$ & Customers (Corporate, SME, Individuals) \\
\hline 6.3 & Group membership & $\mathrm{P}$ & Customers (Corporate, SME, Individuals) \\
\hline 6.4 & Market leadership & $\mathrm{P}$ & Customers (Corporate, SME, Individuals) \\
\hline 6.5 & Attractivity of infrastructures & $\mathrm{P}$ & Customers (Corporate, SME, Individuals) \\
\hline 6.6 & Strong network of branches & $\mathrm{P}$ & Customers (Corporate, SME, Individuals) \\
\hline 6.7 & Care for environment and community & $\mathrm{P}$ & Customers (Corporate, SME, Individuals) \\
\hline
\end{tabular}

